\title{
Based on Multimedia and Network Social Environment-—A study of Pragmatic Acquisition in College English Teaching
}

\begin{abstract}
Jianan Li
Harbin Engineering University, Harbin 150001, China

Jianan Li (1981-), female, native of Harbin, Heilongjiang Province, Department of Foreign Languages, lecturer, master, research direction: English Language and Literature, translation.

Funding: 2020 The subject of Educational Science in Heilongjiang Province: Studies on cultural conflicts in English flipped classes. (GJB1320065); 2020 The subject of Educational Science in Heilongjiang Province: A Study on Metaphorical Translation Strategies and The Teaching Applications in Belt and road Political and Economic Texts(GJC1318022).

Abstract: With the progress of the times, the number of college students is growing exponentially. But the students who enter the university are various and have their own advantages and disadvantages. Among them, the polarization of students' English level is particularly obvious and serious. Therefore, in view of the contradiction between "not enough to learn" and "unable to learn", this paper makes a preliminary exploration on the pragmatic acquisition mode of College English teaching based on multimedia and network social environment. This paper mainly discusses and analyzes the concept of pragmatic acquisition mode and about how to implement it in practical teaching. In addition, this paper is only for reference in the English teaching industry.
\end{abstract}

Key words: The pragmatic acquisition model; College English Teaching; Multimedia and network social environment

Publication date: April, 2021; Publication online: 30 April, 2021

*Corresponding author: Jianan Li, LJN8238@163.com

In recent years, with the development of the times, the number of students entering the university is growing by leaps and bounds. However, due to the fact that there are students from all over the country in the university classroom, their English education is also unbalanced. For example, Some students begin to contact with English from kindergarten, and some students learning English only for passing the English exams and have no interest in English. In addition, some students are good at English since childhood, but some students are born with great difficulties in language learning, which leads to their difficulties of learning English. Therefore, the initial freshness of language has long been submerged by the heavy learning task of colleges ${ }^{[1]}$. As a result, some students can't learn any knowledge in English class, while others can't understand what the teacher says. This kind of contradiction also promotes the emergence of new teaching mode. Therefore, this paper explores the pragmatic acquisition mode of College English teaching based on multimedia and network social environment, which is only for reference in the English teaching industry.

\section{Theoretical Basis}

The learning theory of "pragmatic acquisition" refers to a kind of learning skill that enables students to develop their learning ability subconsciously through natural and common use of language in daily communication environment ${ }^{[2]}$. The research shows that in this learning environment, the vast majority of students have no great differences in learning motivation, learning ability and learning speed. On the contrary, environmental factors have a greater impact on students, and the decisive factors at this time depend on the environmental conditions of schools and families. As long as students can accept a reasonable way of education, they can 
learn anything in the world, which is the pragmatic acquisition theory ${ }^{[3]}$.

\section{Implementation Steps \\ 2.1 Design Unit Plan}

Designing unit plan is the most important link to determine teaching objectives and teaching contents in English teaching. The most important carrier of the theory of pragmatic acquisition can be successfully implemented is unit plan. Only by designing the teaching materials can we grasp the central topic of each unit, and can we focus on the unit objectives and English learning elements to the students. Only by doing a good job in the teaching materials can we grasp the teaching key points and cultivate the students' literacy and ability. The purpose of the design unit plan is to let the teacher master the knowledge required by the unit and implement. It gradually accords to the class schedule. Only after the key and difficult points of each unit are clearly defined can the key and difficult points of each unit be penetrated into each text, and the students can learn the skills they should know more emphatically.

\subsection{Assign Learning Tasks}

Because the students who study college English are all college students, they have the ability of independent learning and thinking, so before English teaching, we should tell the students the teaching content and teaching objectives, so that students can clearly grasp the general learning content and learning objectives of the unit ${ }^{[5]}$. On this basis, the teacher explains in each part of the teaching content, what kind of preparation students need to make before class, what videos and books students can refer to, or what knowledge and ability they need to have and what knowledge points they need to master. Finally, according to the plan of the course, students should be assigned learning tasks. While giving students certain preparation time, students should also be urged to complete their tasks.

When arranging learning tasks, it can be divided into two forms: individual task and group task. Individual task is a task that requires each student to complete, such as preview the words, listening to text and audio, and completing exercises after class. The group task can be a group of 4-6 students, which can form a learning group, which on the one hand plays a brainstorming role, on the other hand, it also allows students with relatively poor learning performance to participate in the course, so that the students who study well can help to coach the students with poor learning to achieve the role of learning achievement progress ${ }^{[6]}$.

\subsection{Autonomous Collaborative Learning}

After a period of preview, review and searching for materials, the students have completed the learning content assigned by the teacher, and then they can enter the classroom. In class, teachers need to make multimedia courseware in advance, so as to improve students' ability from listening, speaking, reading and writing. At the same time, it also increases students' interest in class from pictures, video, audio, interesting text and other aspects. Multimedia courseware is a more vivid interpretation of English words, syntax, grammar and text structure. It is a tool to show students a variety of forms, diversified and diversified classroom through the Internet. Through multimedia, students can have all-round sensory stimulation.

Because the learning of English requires students to imitate, follow and practice what they have learned, and College English mainly focuses on improving students' practical ability of using the language, so in College English class, teachers should pay more attention to students' listening and speaking ability, and let students understand English by means of drama, speech, dialogue, games and so on. These English elements required by the ability to consolidate and improve ${ }^{[7]}$.

\subsection{Operation and Testing}

Just completing the classroom task is far from enough to let students master the corresponding knowledge and ability. At this time, we need to practice to consolidate students' learning of classroom knowledge, and we need to test to let students and teachers understand students' mastery of knowledge.

Teachers can understand the students' learning situation through the students' homework at ordinary times, and can roughly clarify the students' learning effect through the ordinary small questions and the students' performance in the classroom. In this era, multimedia and network are very developed. We can make full use of the convenience and interactivity of the network, and use all kinds of analysis data to let students know their own shortcomings according to their usual homework, so as to feed back to teachers in time, so that teachers can understand the students' real mastery of the knowledge, so as to adjust according to the students' learning progress in time.

The purpose of formative testing is to let students review and consolidate their knowledge in time, and also to let teachers understand students' learning ability and their own learning attitude. Through the unit test, both students and teachers can adjust the content of the next unit in learning and 
teaching.

In addition to the usual assignments and unit tests, the mid term and final examinations should also be arranged for each semester. The purpose of the mid-term test is to adjust students' learning status in time, and the purpose of the final exam is to test students' learning achievements. After the midterm test, the students will analyze the past half semester, and also urge the students to adjust their learning state from a different perspective and seriously engage in their study. After the final examination, we can understand the students' English level, so that students can make a reasonable plan for his future, and also put forward a positive or negative judgment for his follow-up English learning.

\subsection{Extension}

After passing the unit test, teachers also need to use the network to collect and select appropriate information for students, so as to provide the learning progress of students at different stages. Teachers can choose any topic consistent with the key and difficult points of this unit in the resource library as extra-curricular supplementary materials for students to learn[8]. Students with poor academic performance are still in groups, forming a group form of "unity and mutual assistance", in which eugenics drive poor students, eugenics teach poor students, and poor students infect ordinary students, so as to achieve the goal of win-win cooperation.

For the students who fail the unit test, the content of expanding this section should be a supplementary review of the knowledge learned before the University, and the knowledge points involved in this unit should be intensively strengthened. For the places that teachers don't understand in class, they should repeatedly learn from multimedia courseware and the information collected on the network, and ask teachers or superior students for knowledge, so as to cultivate their ability of listening, speaking, reading and writing.

\subsection{Evaluation of Learning Results}

At the end of each class, teachers should reflect on and summarize the situation of the classroom. For the students who do not do well, we should make comments. According to the students' homework and test situation, teachers also need to evaluate the results of the whole learning situation. Pragmatic acquisition is mainly to let students play their subjective initiative, and make students achieve a process of natural knowledge through the continuous repetition of the living language. The goal of acquisition is to give full play to the students' learning enthusiasm and fully explore their learning potential, so that students can easily grasp the required abilities in daily communication and in conversation. At the end of the evaluation of teaching results, there should be encouragement to students and praise for the achievements made by students. Of course, there will be criticism. Criticism should be made for students' unconscious and serious learning status. However, the main purpose of pragmatic acquisition is to make students feel the charm of language and the joy of learning, so as to provide driving force for students to continue learning. The university mainly focuses on the cultivation of students' self-study ability. Therefore, teachers should focus on not how much students master knowledge, but also the increase and decrease of students' fun in learning English, and whether they can improve their learning methods and independent self-study ability.

\section{Conclusion}

Based on the multi-media and network social environment, the pragmatic acquisition mode of College English teaching solves the major contradiction of "not enough to learn" and "unable to learn" in the classroom, and puts forward an effective solution to the problem of polarization of students' English performance, which provides some students with the possibility of in-depth learning to a certain extent, and also makes students understand that knowledge is more effective. Of course, no matter what kind of teaching mode, there will be its own drawbacks. "Acquisition" mode tends to let students understand themselves, set the classroom as a situation, let students experience the context, so as to naturally and imperceptibly learn English expression. However, it depends on the strong self-control of students to achieve the goal ${ }^{[10]}$.

Students must complete the tasks assigned by teachers within the specified time, and be able to resist the temptation of other aspects. When they get a mobile phone or computer to learn English, they should control their own thoughts, and have the ability of network screening and discrimination. Under certain conditions, this also puts forward requirements for students' self-control ability.

Of course, some students will take the homework assigned by teachers seriously, and the completion and accuracy of homework are very high, which requires teachers to improve their ability to make multimedia courseware, to control students' questions in teaching, to control the classroom, and so on.

Therefore, the teaching method of pragmatic acquisition 
mode in College English teaching based on multimedia and network social environment is feasible to a certain extent. For some unavoidable deficiencies in the implementation process, rewards and punishment measures can also be taken to make up for them.

\section{References}

[1] Chen F. Discussion on foreign trade English Correspondence Teaching under multimedia network environment $[\mathrm{J}]$. Journal of Hubei Radio and TV University, 2014(5): 21-22.

[2] Duan AH, Zhang HQ. Application of peer feedback in College English Writing Teaching under multimedia network environment $[\mathrm{J}]$. Journal of Changchun University of technology, 2014 (6): 13-15.

[3] Ma S. Discussion on College English classroom teaching mode under multimedia network environment [J]. Campus English, 2016 (12): 26.

[4] Xue MW. Discussion on College English classroom teaching mode under multimedia network environment [J]. Journal of Hubei Radio and TV University, 2014 (2): 60-62.
[5] Yu B. On how to realize service outsourcing teaching in the multimedia network environment $[\mathrm{J}]$. Market of science and technology economy, 2014 (6): 31-33.

[6] Xu M. Analysis of College English teaching mode in the multimedia and network environment [J]. English Square, 2016 (10): 3-5.

[7] Zeng QX, Xie LP. Analysis of College English teaching mode based on multimedia and network -- Taking WebQuest Teaching Mode and flipped classroom teaching mode as examples [J]. English Square, 2016 (1): 59-62.

[8] Li XH. Exploration of College English teaching mode under multimedia and network environment $[\mathrm{J}]$. Private science and technology, 2016 (7): 265.

[9] Ding H. Innovation of College English classroom teaching mode under multimedia network environment [J]. Journal of Heilongjiang Institute of education, 2015,34 (1): 151-152.

[10] Huang J. Research on College English teaching mode based on multimedia and network environment $[\mathrm{J}]$. Scientific Chinese, 2016 (3): 131. 